\title{
ANALISIS PENGARUH RASIO PROFITABILITAS TERHADAP HARGA SAHAM PERUSAHAAN YANG TERCANTUM DALAM INDEKS LQ45
}

\author{
Haidar Abdullah \\ shinvivid7@gmail.com \\ Universitas Ahmad Dahlan \\ Salamatun Asakdiyah \\ salamatun_2009@yahoo.com \\ Universitas Ahmad Dahlan
}

\begin{abstract}
ABSTRAK
This study aimed to examine the effect of profitability ratio on stock price of companies listed in LQ45 index in Indonesia Stock Exchange (BEI). Profitability ratios here in include Net Profit Margin (NPM), Return on Assets (ROA), Return on Equity (ROE), and Eearning Per Share (EPS). This study was conducted to assess the financial performance of the company to generate earnings from an investment.This study uses secondary data. The population in this study is the companies included in the LQ45 index from 2010-2013 amounting to 78 . The total sample is 16 companies belonging to and representing several sectors including the financial sector companies, automotive, property, plantation, infrastructure, mining, industrial cement, as well as the consumer goods industry are consistently incorporated in the four observation period 2010-2013 in LQ45 index that has been determined through purposive sampling method. Method of hypothesis testing using Classical Assumption Test, Regression, t test, $\mathrm{F}$ test, and the coefficient of determination by alpha $(\alpha)$ of $5 \%$.Regression analysis showed that in partial Net Profit Margin (NPM), Return on Assets (ROA) and Return On Equity (ROE) significantly influence the stock price while the variable Eearning Per Share (EPS) has no significant effect on stock price. Simultaneously all variables Net Profit Margin (NPM), Return on Assets (ROA), Return on Equity (ROE), and Eearning Per Share (EPS) have a significant effect on stock price. The value of coefficient of determination (R2) of 0.899 , which means that the independent variable Net Profit Margin (NPM), Return on Assets (ROA), Return on Equity (ROE), and Eearning Per Share (EPS) is able to explain the variation of the dependent variable stock price by $89,9 \%$, while the remaining $10.1 \%$ is explained by other variables outside of the variables used in the study.
\end{abstract}

Keywords: Stock Price, Net Profit Margin (NPM), Return On Asset (ROA), Return On Equity (ROE), Earning Per Share (EPS).

\begin{tabular}{l}
\hline PENDAHULUAN \\
\cline { 1 - 1 } \\
Pasar modal memiliki peran penting \\
bagi perekonomian suatu negara karena \\
pasar modal menjalankan dua fungsi, \\
yaitu pertama sebagai sarana bagi \\
pendanaan usaha atau sebagai sarana bagi \\
perusahaan untuk mendapatkan dana dari \\
masyarakat pemodal (investor). Dana
\end{tabular}

yang diperoleh dari pasar modal dapat digunakan untuk pengembangan usaha, ekspansi, penambahan modal kerja dan lain-lain, kedua pasar modal menjadi sarana bagi masyarakat untuk berinvestasi pada instrument keuangan seperti saham, obligasi, reksa dana, dan lain-lain. Dengan demikian, masyarakat dapat menempatkan dana yang dimilikinya 
sesuai dengan karakteristik keuntungan dan risiko masing-masing instrument.

Martono (2003) menjelaskan Pasar modal terdiri dari pasar primer (primary market) dan pasar sekunder (secondary market). Pasar primer adalah pasar untuk surat-surat berharga yang baru diterbitkan. Pada pasar ini dana berasal dari arus penjualan surat berharga atau sekuritas (security) baru dari pembelisekuritas (investor) kepada perusahaan yang menerbitkan sekuritas tersebut (emiten). Sedangkan pasar sekunder adalah pasar perdagangan surat berharga yang sudah ada (sekuritas lama) di bursa efek. Uang yang mengalir dari transaksi ini tidak lagi mengalir ke perusahaan penerbit efek tetapi hanya mengalir dari pemegang sekuritas yang satu kepada pemegang sekuritas yang lain.

Pasar modal Indonesia memiliki peran besar bagi perekonomian negara. Dengan adanya pasar modal (capital market), investor sebagai pihak yang memiliki kelebihan dana dapat menginvestasikan dananya pada berbagai sekuritas dengan harapan memperoleh imbalan (return). Sedangkan perusahaan sebagai pihak yang memerlukan dana dapat memanfaatkan dana tersebut untuk mengembangkan proyek-proyeknya. Dengan alternatif pendanaan dari pasar modal, perusahaan dapat beroperasi dan mengembangkan bisnisnya dan pemerintah dapat membiayai berbagai kegiatannya sehingga meningkatkan kegiatan perekonomian negara dan kemakmuran masyarakat luas (Tandelilin, 2010).

Undang-undang Pasar Modal No. 8 Tahun 1995 tentang Pasar Modal mendefinisikan pasar modal sebagai kegiatan yang bersangkutan dengan Penawaran Umum dan Perdagangan Efek, Perusahaan Publik yang berkaitan dengan Efek yang diterbitkannya, serta lembaga dan profesi yang berkaitan dengan Efek.

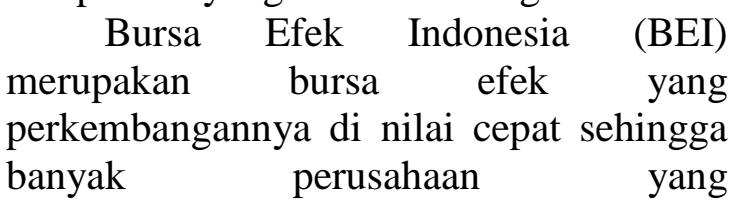

memanfaatkannya untuk mencari dana. Perkembangan bursa efek disamping dilihat dengan semakin banyaknya anggota bursa juga dapat dilihat dari perubahan harga saham yang diperdagangkan. Menurut Darmadji (2008) Bursa Efek adalah lembaga atau perusahaan yang menyelenggarakan atau menyediakan fasilitas sistem (pasar) untuk mempertemukan penawaran jual dan beli efek antarberbagai perusahaan atau perorangan yang terlibat dalam tujuan perdagangan efek perusahaan-perusahaan yang telah tercatat di Bursa Efek.

Mulyono (2000) mengatakan bahwa ekspektasi untuk memperoleh pendapatan yang lebih besar dimasa mendatang berpengaruh positif terhadap harga

saham. Variasi harga saham ditentukan oleh banyak faktor, baik yang berasal dari

lingkungan eksternal maupun internal perusahaan. Seorang investor dalam

menginvestasikan sahamnya perlu memperhatikan faktor-faktor tersebut, mengingat

harga saham itu sendiri sangat sulit ditebak kapan saham itu turun dan kapan saham

itu naik, investor hanya bisa memprediksi dengan kecenderungan, kinerja historis

dan pergerakan saham.

Dalam menentukan saham yang akan dibeli atau dijual investor perlu mempertimbangkan informasi yang tersedia. Informasi ini berguna sebagai pertimbangan untuk menentukan tingkat keuntungan beserta resiko saham yang dibeli atau dijual. Investor yang menginvestasikan dananya pada sekuritas, berkepentingan terhadap keuntungan saat ini dan keuntungan dimasa yang akan datang serta adanya stabilitas dari keuntungan yang akan diperoleh. Sebelum menginvestasikan dananya investor melakukan analisis terhadap kemampuan perusahaan dalam menghasilkan keuntungan. Investor juga berkepentingan 
atas informasi yang berhubungan dengan kondisi atau kinerja keuangan perusahaan sebagai pedoman untuk melakukan investasi, supaya dana yang diinvestasikan tersebut mampu menghasilkan nilai tambah dimasa mend atang dalam bentuk dividen (capital gain). Investor juga berkepentingan untuk memilih perusahaan mana diantara begitu banyak sektor perusahaan yang dituju yang nantinya dapat memberikan keuntungan bagi investor itu sendiri, dengan melihat perolehan laba bersih tahunan perusahaan tersebut, guna untuk memperkecil resiko yang ditanggung.

Harga saham suatu perusahaan menunjukkan nilai penyertaan dalam perusahaan. Tinggi rendahnya harga saham suatu perusahaan dipengaruhi oleh banyak faktor seperti kinerja perusahaan, resiko, dividen, tingkat suku bunga, penawaran, permintaan, laju inflasi, kebijaksanaan pemerintah dan kondisi perekonomiaan. Karena perubahan faktor-faktor di atas harga saham akan mengalami perubahan naik atau turun. Harga saham mencerminkan nilai perusahaan dimata masyarakat. Apabila harga saham suatu perusahaan tinggi, maka nilai perusahaan dimata masyarakat juga baik dan sebaliknya jika harga saham perusahaan rendah, maka nilai perusahaan dimata masyarakat menjadi kurang baik, maka harga saham merupakan hal yang penting bagi perusahaan.

Rasio keuangan dapat digunakan sebagai dasar pembuatan keputusan, serta untuk membandingkan kinerja perusahaan yang satu dengan yang lainnya. Dari sisi eksternal, rasio keuangan digunakan untuk menentukan pembelian atau penjualan saham suatu perusahaan, pemberian pinjaman serta untuk memprediksi kekuatan keuangan perusahaan di masa mendatang. Analisis rasio keuangan dapat membantu para pelaku bisnis, pemerintah dan para pemakai laporan keuangan lainnya untuk menilai kondisi keuangan suatu perusahaan.

Dari sudut pandang investor, salah satu indikator penting untuk menilai prospek perusahaan di masa yang akan datang adalah dengan melihat sejauh mana pertumbuhan profitabilitas perusahaan. Indikator ini sangat penting diperhatikan untuk mengetahui sejauh mana investasi yang akan dilakukan investor di suatu perusahaan mampu memberikan return yang sesuai dengan tingkat yang disyaratkan investor (Tandelilin, 2010).

Investor mengukur kinerja perusahaan berdasarkan kemampuan beberapa

perusahaan dalam mengelola sumber dana yang dimiliki untuk menghasilkan

keuntungan. Jika suatu perusahaan memiliki kinerja keuangan yang baik maka

investor akan menanamkan modalnya, karena dapat dipastikan akan memperoleh

keuntungan dari penanaman modal tersebut. Penilaian kinerja keuangan perusahaan

dalam menghasilkan laba dari investasi ini disebut sebagai rasio profitabilitas atau

rentabilitas.

Dalam penelitian ini mengapa menggunakan rasio profitabilitas, karena rasio profitabilitas adalah rasio yang pertama kali yang perlu di perhatikan oleh seorang investor ketika akan menanamkan modalnya pada suatu perusahaan. Rasio profitabilitas diantaranya Net Profit Margin (NPM), Return On Assets (ROA), Return On Equity (ROE), dan Eearning Per Share (EPS), karena secara teori keempat rasio profitabilitas tersebut berpengaruh positif terhadap harga saham, maka apabila Net Profit Margin (NPM), Return On Assets (ROA), Return On Equity (ROE), dan Eearning Per Share (EPS) tinggi maka harga saham akan 
meningkat dan akan memperoleh laba yang tinggi pula.

Indeks LQ45 sebagai salah satu indikator indeks saham di BEI dapat dijadikan acuan sebagai bahan untuk menilai kinerja perdagangan saham. Indeks ini terdiri dari 45 saham yang lolos seleksi menurut beberapa kriteria pemilihan dengan likuiditas tinggi dan kapitalisasi pasar yang besar.

Dari penjelasan latar belakang diatas, peneliti akan melakukan penelitian beberapa faktor penting dari rasio profitabilitas diantaranya Net Profit Margin (NPM), Return On Assets (ROA), Return On Equity (ROE), dan Eearning Per Share (EPS) apakah berpengaruh terhadap harga saham perusahaan yang tercantum dalam indeks LQ45 di Bursa Efek Indonesia.

\section{REVIEW LITERATUR DAN HIPOTESIS}

\section{Landasan Teori}

\section{Saham}

Martono (2003) menjelaskan saham adalah surat bukti atau tanda kepemilikan bagian modal pada suatu perusahaan.

\section{Indeks LQ45}

Menurut Tandelilin (2010) Intensitas transaksi setiap sekuritas di pasar modal berbeda-beda. Sebagian sekuritas memiliki frekuensi yang sangat tinggi dan aktif diperdagangkan di pasar modal, namun sebagian sekuritas la innya relatif sedikit frekuensi transaksi dan cenderung bersifat pasif. Hal ini menyebabkan perkembangan dan tingkat likuiditas IHSG menjadi kurang mencerminkan kondisi real yang terjadi di bursa efek. Di Indonesia persoalan tersebut dipecahkan dengan menggunakan indeks LQ45. Indeks LQ45 terdiri dari 45 saham di BEI dengan likuiditas yang tinggi dan kapitalisasi pasar yang besar serta lolos seleksi menurut beberapa kriteria pemilihan.

\section{Net Profit Margin (NPM)}

Menurut Asakdiyah (2006) Net Profit Margin merupakan keuntungan atau laba bersih per rupiah penjualan. NPM dapat dihitung dengan membandingkan antara laba bersih setelah dikenakan pajak dengan penjualan bersih.

$$
\text { NPM }=\frac{\text { Laba Bersih }}{\text { Penjualan }}
$$

4. Return On Assets (ROA)

Prastowo (2011) menjelaskan

Return on Assets mengukur kemampuan perusahaan dalam memanfaatkan aktivanya untuk memperoleh laba. Rasio ini mengukur tingkat kembalian investasi yang telah dilakukan oleh perusahaan dengan menggunakan seluruh dana (aktiva) yang dimilikinya. Rasio ini dapat diperbandingkan dengan tingkat bunga bank yang berlaku.

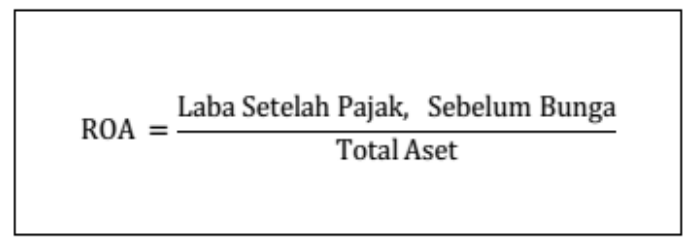

\section{Return On Equity (ROE)}

Menurut Mardiyanto (2009) ROE adalah rasio yang digunakan untuk mengukur keberhasilan perusahaan dalam menghasilkan laba bagi para pemegang saham. ROE dianggap sebagai representasi dari kekayaan pemegang saham atau nilai perusahaan.

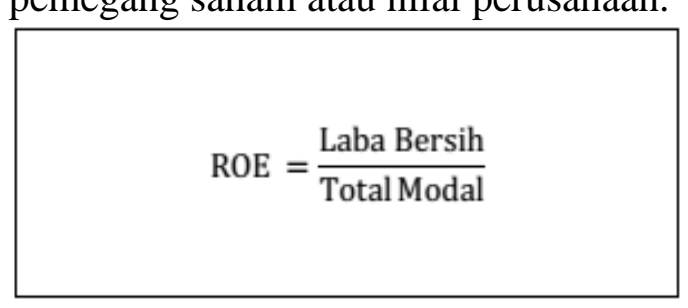


6. Earning Per Share (EPS)

Darmadji (2008) menyatakan

Laba per saham (Earning per Share) merupakan rasio yang menunjukkan bagian laba untuk setiap saham. EPS menggambarkan profitabilitas perusahaan yang tergambar pada setiap lembar saham. Semakin tinggi nilai EPS tentu saja menyebabkan semakin besar laba dan kemungkinan peningkatan jumlah dividen yang diterima pemegang saham.

$$
\text { EPS }=\frac{\text { Laba Bersih }}{\text { Jumlah Saham Beredar }}
$$

\section{Penelitian Terdahulu}

Sulistiyanto (2013) meneliti pengaruh Earning Per Share (EPS), Return on Assets (ROA), Return on Equity (ROE), Net Profit Margin (NPM), dan Price Earning Ratio (PER) terhadap harga saham (Studi pada perusahaan Industri Farmasidi Bursa Efek Indonesia), hasilnya secara parsial variabel independen yaitu Earning Per Share (EPS), Return on Assets (ROA), Price Earning Ratio (PER) mempunyai pengaruh yang signifikan terhadap harga saham. Sedangkan variabel independen Return on Equity (ROE), Net Profit Margin (NPM) tidak berpengaruh signifikan terhadap harga saham. Hasil secara simultan bahwa Earning Per Share (EPS), Return on Assets (ROA), Return on Equity (ROE), Net Profit Margin (NPM), dan Price Earning Ratio (PER) berpengaruh signifikan terhadap harga saham pada perusahaan farmasi di Bursa Efek Indonesia 2007-2011.

Wibowo (2011) meneliti tentang pengaruh Earning Per Share (EPS), Net Profit Margin (NPM), Price to Book Value (PBV), Price Earning Ratio (PER), Return on Equity (ROE), dan Return on Invesment (ROI) terhadap harga saham pada perusahaan perbankan yang terdaftar di Bursa Efek Indonesia tahun 2009. Secara parsial hanya variabel Earning Per Share (EPS) dan Price to Book Value (PBV) yang berpengaruh signifikan terhadap harga saham, sedangkan secara simultan variabel Earning Per Share (EPS), Net Profit Margin (NPM), Price to Book Value (PBV), Price Earning Ratio (PER), Return on Equity (ROE), dan Return on Invesment (ROI) berpengaruh signifikan terhadap harga saham.

\section{Hipotesis}
H1: Net Profit Margin (NPM) berpengaruh signifikan terhadap harga saham

H2: Return On Assets (ROA) berpengaruh signifikan terhadap harga saham
H3: Return On Equity (ROE) berpengaruh signifikan terhadap harga saham
H4: Earning Per Share (EPS) berpengaruh signifikan terhadap harga saham

H5: Net Profit Margin (NPM), Return On Assets (ROA), Return On Equity(ROE), dan Earning Per Share (EPS) secara simultan berpengaruh signifikan terhadap harga saham

\section{METODE PENELITIAN}

\section{Populasi dan Sampel}

Populasi dalam penelitian ini adalah seluruh perusahaan yang masuk dalam LQ45 selama tahun penelitian 2010-2013 yakni sebanyak 78 perusahaan.

Sampel yang diteliti menggunakan purposive sampling sesuai dengan kriteriakriteria yang telah di tentukan. Jogiyanto (2010) mengemukakan bahwa pengambilan sampel bertujuan (purposive sampling) dilakukan dengan mengambil sampel dari populasi berdasarkan suatu 
kriteria tertentu. Pemilihan sampel dengan dibatasi kriteria tertentu diantaranya sebagai berikut:

1. Terdaftar dalam LQ45 dari tahun 20102013 secara berturut-turut.

2. Tersedia data laporan keuangan perusahaan selama periode penelitian.

3. Memiliki kelengkapan data sesuai dengan faktor-faktor rasio profitabilitas yang akan diteliti.

4. Tergolong dan mewakili dalam sektor keuangan, otomotif, property, perkebunan, infrastruktur, pertambangan, industri semen, serta industri barang konsumsi.

5. Harga saham yang digunakan adalah harga penutupan (closing pric adjusted) rata-rata per tahun.

Berdasarkan kriteria diatas maka peneliti telah menemukan sejumlah 16 sampel dari perusahaan-perusahaan yang masuk dalam LQ45 selama tahun 20102013.

\section{Uji Instrumen}

1. Uji Asumsi Klasik

a. Normalitas

Menurut Kusuma (2012) Salah satu asumsi dalam analisis statistika adalah data berdistribusi normal. Pada program Eviews dapat menggunakan uji Jarque-Bera untuk menguji normalitas.

Bila nilai prob. J-B lebih besar dari $\alpha 5 \%$ (prob. J-B > 0,05), maka data berdistribusi normal. Uji normalitas dapat dilakukan pada beberapa variabel sekaligus atau satu per satu. Dan bila perlu, residual dari persamaan regresi dapat juga dilakukan uji normalitas jika sudah dianalisis regresinya terlebih dahulu.

b. Autokorelasi

Menurut Kusuma (2012) Autokorelasi adalah hubungan antara residual satu observasi dengan observasi lainnya. Setiap data residual pada suatu observasi diharapkan saling bebas dengan observasi lainnya atau tidak ada autokorelasi. Autokorelasi lebih mudah terjadi pada data yang sifatnya runtut waktu (time series), karena sifat datanya yang biasanya dipengaruhi oleh data sebelumnya. Autokorelasi juga dimungkinkan terjadi pada data antar objek (cross section). Autokorelasi dapat berbentuk positif dan negatif.Autokorelasi dapat menyebabkan estimator OLS tidak lagi memiliki varians yang minimum, walaupun koefisien taksiran regresi tetap bersifat tidak bias. Pemeriksaan terhadap dugaan adanya autokorelasi dapat menggunakan Uji B-G sering juga disebut sebagai uji LM (Lagrange Multiplier). Uji ini dapat menutupi kelemahan pada uji D-W ketika memberikan hasil "tidak ada kesimpulan". Pengambilan keputusan dapat dilakukan sebagai berikut:

Prob. Chi Square > 0,05 $\rightarrow$ tidak terjadi autokorelasi

Prob. Chi Square $<0,05 \rightarrow$ terjadi autokorelasi

c. Heteroskedastisitas

Menurut Kusuma Heteroskedastisitas adalah kondisi dimana nilai varians error untuk setiap data pengamatan tidak konstan atau $\operatorname{var}(\mathrm{ei})=\sigma 2 \mathrm{i}$. Salah satu asumsi dalam model regresi dengan OLS adalah nilai error atau residual memiliki varians yang konstan $\operatorname{var}(\mathrm{ei})=\sigma 2 \mathrm{atau}$ disebut juga homoskedastisitas. Pada kenyataannya nilai residual sulit memiliki varian konstan, yang membuat nilai taksiran varians dan standar error koefisien regresi 
menjadi tidak efisien (underestimate) sehingga pengujian hipotesis dengan uji $\mathrm{t}$ menjadi tidak valid (overestimate). Heteroskedastisitas sering dijumpai pada data yang sifatnya cross section daripada time series.

Menurut Kusuma (2012)
Metode yang digunakan untuk
mengidentifikasi terjadinya
heteroskedastisitas pada analisis
regresi menggunakan OLS, yakni
Uji BPG merupakan uji yang
memerlukan pengurutan dan
penghilangan data. Pengambilan
keputusan dengan program Eviews
6 adalah sebagai berikut:
Prob. Chi Square (p-value) $>0,05$
$(\alpha) \quad \rightarrow$ tidak terjadi
heteroskedastisitas
Prob. Chi Square (p-value) $<0,05$
$(\alpha) \rightarrow$ terjadi heteroskedastisitas

d. Multikolinieritas

Menurut Kusuma (2012) Multikolinearitas merupakan salah satu masalah dalam analisis regresi dengan OLS, yang berarti terdapat korelasi atau hubungan yang sangat tinggi di antara variabel independen. Multikolinearitas hanya terjadi pada regresi majemuk, karena melibatkan beberapa variabel independen sehingga tidak terjadi pada regresi sederhana.

\section{Teknik Analisis Data}

1. Analisis Regresi Berganda

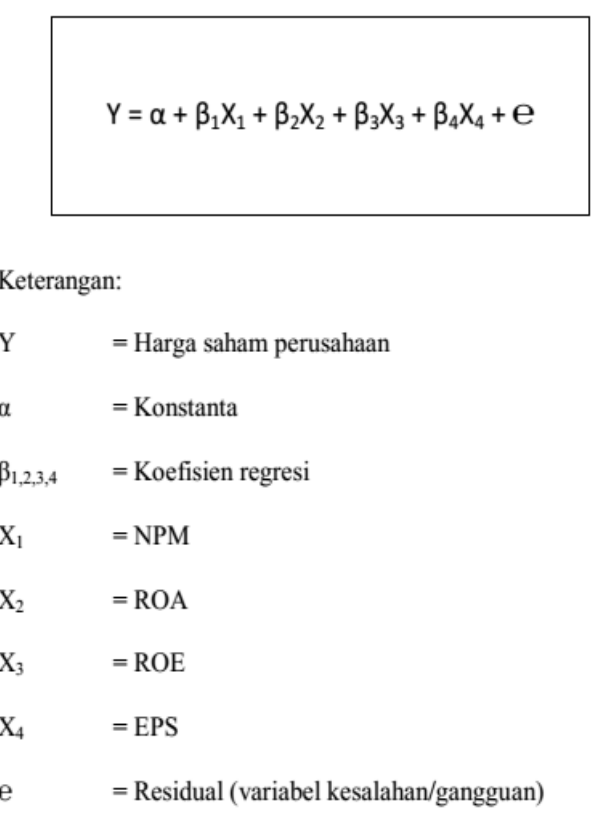

Menurut Kusuma (2012) dalam menentukan model pemilihan estimasi dalam regresi data panel adalah sebagai berikut:

1. Regresikan data panel dengan metode common effect.

2. Regresikan data panel dengan metode fixed effect.

3. Lakukan pengujian dengan uji Chow untuk menentukan apakah metode common effect atau metode fixed effect yang digunakan.

Prob. Chi square $<0,05 \rightarrow$ fixed effect

Prob. Chi square $>0,05 \rightarrow$ common effect

4. Bila keputusannya menerima common effect maka penentuan model berhenti sampai disini, berarti model yang tepat adalah common effect (OLS)

5. Bila hasil dari uji Chow memberikan keputusan menerima fixed effect, lanjutkan meregresikan data panel dengan random effect.

6. Lakukan pengujian dengan uji Hausman apakah metode fixed effect atau random effect yang akan digunakan. 
Prob. Cross section random $<0,05 \rightarrow$ fixed effect

Prob. Cross section random $>0,05 \rightarrow$ random effect

\section{Uji Hipotesis}

\section{Uji Parsial (Uji T)}

Menurut Ghozali (2009) Uji T pada dasarnya menunjukkan seberapa jauh pengaruh satu variabel independen terhadap variabel dependen dengan menganggap variabel lainnya konstan.

Untuk melihat pengaruh secara parsial adalah melihat nilai probabilitasnya, apabila nilai probabilitas yang terbentuk dibawah $5 \%$ maka terdapat pengaruh yang signifikan variabel independen secara parsial terhadap variabel dependen. Sebaliknya bila nilai probabilitas yang terbentuk diatas $5 \%$ maka tidak terdapat pengaruh yang signifikan variabe independen secara parsial terhadap variabel dependen.

\section{Uji Simultan (Uji F)}

\section{Menurut Ghozali (2009) Uji F} pada dasarnya menunjukkan apakah semua variabel independen yang dimasukkan dalam model mempunyai pengaruh secara bersama-sama atau simultan terhadap variabel dependen.

Tolak H0 jika angka Prob (F-statistic) lebih kecil dari $\alpha=5 \%$

Terima H0 jika angka Prob (F-statistic) lebih besar dari $\alpha=5 \%$

\section{Uji Koefisien Determinasi}

$$
\text { Menurut Algifari }
$$

Koefisien determinasi dapat digunakan sebagai petunjuk untuk mengetahui sejauhmana variabel independen dapat menjelaskan variasi variabel dependen.
Biasanya koefisien determinasi adalah kuadrat dari koefisien korelasi.

\section{HASIL PENELITIAN DAN PEMBAHASAN}

\section{Hasil Penelitian}

1. Hasil Uji Asumsi Klasik

a. Normalitas

\begin{tabular}{|c|c|}
\hline Jarque-Bera & 25.26085 \\
\hline Probability & 0.000003 \\
\hline
\end{tabular}

Berdasarkan hasil tersebut, maka residual persamaan regresi tersebut berdistribusi tidak normal karena nilai prob. J-B sebesar $0,000003<0,05$.

b. Autokorelasi

\begin{tabular}{|llll|}
\hline Breusch-Godfrey & Serial Correlation LM Test \\
\hline F-statistic & 7.870754 & Prob.F(2.57) & 0.0010 \\
Obs*R-squared & 13.84982 & Prob. Chi-Square(2) & 0.0010 \\
\hline
\end{tabular}

Berdasarkan hasil uji B-G diatas menunjukkan nilai prob. ChiSquare adalah 0,0010 yang mana lebih kecil dari 0,05 artinya terjadi autokorelasi.

\begin{tabular}{|lrlr|}
\hline \multicolumn{4}{|l|}{ Breusch-Godfrey Serial Correlation LM Test } \\
\hline F-statistic & 4.903112 & Prob.F(2.57) & 0.0108 \\
Obs*R-squared & 9.394309 & Prob. Chi-Square(2) & 0.0091 \\
\hline \multicolumn{4}{c}{ Berdasarkan } \\
uji & B-G
\end{tabular}
menunjukkan adanya masalah autokorelasi, terbukti dari nilai prob. Chi Square < 0,05 $(0,0091$ $<$ 0,05). Dengan melakukan transformasi data dalam bentuk invers di atas masih belum dapat menghilangkan masalah autokorelasi yang terjadi sebelumnya.

c. Heteroskedastisitas

\begin{tabular}{|llll|}
\hline \multicolumn{4}{|l|}{ Heteroskedasticity Test: Breusch-Pagan-Godfrey } \\
\hline F-statistic & 2.026505 & Prob.F(4.59) & 0.1023 \\
Obs*R-squared & 7.730832 & Prob. Chi-Square(4) & 0.1020 \\
Scaled explained SS & 13.09258 & Prob. Chi-Square(4) & 0.0108 \\
\hline
\end{tabular}

Berdasarkan hasil uji BPG diatas menunjukkan nilai prob. ChiSquare pada Obs*R-square adalah 
0,1020 yang mana lebih besar dari $\alpha$ 0,05. Maka tidak terjadi heteroskedastisitas.

d. Multikolinieritas

\begin{tabular}{|c|c|c|c|c|}
\hline \multicolumn{5}{|c|}{ Correlation } \\
\hline & NPM & ROA & ROE & EPS \\
\hline NPM & 1.000000 & 0.182797 & 0.204912 & -0.062768 \\
\hline ROA & 0.182797 & 1.000000 & 0.828759 & 0.087300 \\
\hline ROE & 0.204912 & 0.828759 & 1.000000 & 0.151683 \\
\hline EPS & -0.062768 & 0.087300 & 0.151683 & 1.000000 \\
\hline \multicolumn{5}{|c}{ Dari hasil uji korelasi }
\end{tabular}

antarvariabel independen tersebut terlihat adanya nilai korelasi (derajat keeratan) yang rendah (< 90\%) antar variabel independen. Maka ini menunjukkan tidak adanya gejala multikolinearitas.

2. Hasil Uji Regresi Linier Berganda

\begin{tabular}{|c|c|c|c|c|}
\hline \multicolumn{5}{|c|}{ Dependent Variable: Harga Saham } \\
\hline Variable & Coefficient & Std. Error & t-Statistic & Prob. \\
\hline C & 1490.251 & 1384.499 & 1.076382 & 0.2876 \\
\hline NPM & 262.3888 & 102.3734 & 2.563056 & 0.0139 \\
\hline ROA & -597.1749 & 190.6119 & -3.132935 & 0.0031 \\
\hline ROE & 199.0309 & 75.31837 & 2.642528 & 0.0114 \\
\hline EPS & -0.278730 & 0.591541 & -0.471193 & 0.6398 \\
\hline \multicolumn{5}{|l|}{} \\
Y $=1490,25+262,39 X_{1}-597,17 X_{2}+199,03 X_{3}-0,28 X_{4}+e$ \\
\hline
\end{tabular}

a. Nilai konstanta sebesar 1490,25 berarti bahwa jika variabel NPM, ROA, ROE, dan EPS adalah nol maka nilai Harga Saham pada perusahaanperusahaan LQ45 tersebut akan sama dengan nilai konstanta yaitu sebesar 1490,25.

b. Koefisien regresi NPM (X1) sebesar 262,39 berarti bahwa setiap kenaikan satu nilai dari NPM maka akan memberikan kenaikan Harga Saham pada perusahaan-perusahaan LQ45 tersebut sebesar 262,39 poin. Sebaliknya setiap penurunan satu nilai dari NPM maka akan memberikan penurunan Harga Saham pada perusahaan-perusahaan LQ45 tersebut sebesar 262,39 poin.

c. Koefisien regresi ROA (X2) sebesar $-597,17$ berarti bahwa setiap kenaikan satu nilai dari ROA maka akan memberikan penurunan Harga Saham pada perusahaan-perusahaan LQ45 tersebut sebesar 597,17 poin. Sebaliknya setiap penurunan satu nilai dari ROA maka akan memberikan kenaikan Harga Saham pada perusahaan-perusahaan LQ45 tersebut sebesar 597,17 poin.

d. Koefisien regresi ROE (X3) sebesar 199,03 berarti bahwa setiap kenaikan satu nilai dari ROE maka akan memberikan kenaikan Harga Saham pada perusahaan-perusahaan LQ45 tersebut sebesar 199,03 poin. Sebaliknya setiap penurunan satu nilai dari ROE maka akan memberikan penurunanHarga Saham pada perusahaan-perusahaan LQ45 tersebut sebesar 199,03poin.

e. Koefisien regresi EPS (X4) sebesar -0,28 berarti bahwa setiap kenaikan satu nilai dari EPS maka akan memberikan penurunan Harga Saham pada perusahaan-perusahaan LQ45 tersebut sebesar 0,28 poin. Sebaliknya setiap penurunan satu nilai dari EPS maka akan memberikan kenaikan Harga Saham pada perusahaan-perusahaan LQ45 tersebut sebesar 0,28 poin.

\section{Hasil Uji Parsial (Uji T)}

a. Pengujian secara parsial terhadap variabel NPM dapat dilihat bahwa nilai Prob sebesar 0,0139. Karena angka tersebut lebih kecil dari $\alpha 0,05$ yang merupakan angka derajat kepercayaan, maka H01 ditolak atau Ha1diterima atau dapat disimpulkan bahwa Net Profit Margin (NPM) berpengaruh signifikan terhadap harga saham.

b. Pengujian secara parsial terhadap variabel ROA dapat dilihat bahwa nilai Prob sebesar 0,0031. Karena angka tersebut lebih kecil dari $\alpha 0,05$ yang merupakan angka derajat kepercayaan, maka H02ditolak atau Ha2diterima atau dapat disimpulkan bahwa Return On 
Assets (ROA) berpengaruh signifikan terhadap harga saham.

c. Pengujian secara parsial terhadap variabel ROE dapat dilihat bahwa nilai Prob sebesar 0,0114. Karena angka tersebut lebih kecil dari $\alpha 0,05$ yang merupakan angka derajat kepercayaan, maka H03 ditolak atau Ha3diterima atau dapat disimpulkan bahwa Return On Equity (ROE) berpengaruh signifikan terhadap harga saham.

d. Pengujian secara parsial terhadap variabel EPS dapat dilihat bahwa nilai Prob sebesar 0,6398. Karena angka tersebut lebih besar dari $\alpha$ 0,05 yang merupakan angka derajat kepercayaan, maka H04 diterima atau Ha4ditolak atau dapat disimpulkan bahwa Earning Per Share (EPS) tidak berpengaruh signifikan terhadap harga saham.

4. Hasil Uji Simultan (Uji F)

\begin{tabular}{|llll|}
\hline R-squared & 0.899118 & Mean dependent var & 5224.783 \\
Adjusted R-squared & 0.855556 & S.D. dependent var & 4877.681 \\
S.E. of regression & 1853.801 & Akaike info criterion & 18.13817 \\
Sum squared resid & $1.51 \mathrm{E}+08$ & Schwarz criterion & 18.81282 \\
Log likelihood & -560.4215 & Hannan-Quinn criter. & 18.40395 \\
F-statistic & 20.63974 & Durbin-Watson stat & 1.188201 \\
Prob (F-statistic) & 0.000000 & & \\
\hline
\end{tabular}

Dari hasil output analisis regresi diatas dapat diketahui bahwa secara bersama-sama (simultan) variabel independen memiliki pengaruh yang signifikan terhadap variabel dependen. Hal ini dapat dibuktikan dari nilai Fstatistic sebesar 20,63974 dengan Probabilitas (F-statistic) sebesar 0,000000 . Karena probabilitas jauh lebih kecil dari $\alpha$ 0,05 maka H05 ditolak atau $\mathrm{Ha} 5$ diterima atau dapat disimpulkan bahwa Net Profit Margin (NPM), Return On Assets (ROA), Return On Equity (ROE), dan Earning Per Share (EPS) secara simultan berpengaruh signifikan terhadap harga saham.
5. Hasil Uji Koefisien Determinasi

\begin{tabular}{|llll|}
\hline R-squared & 0.899118 & Mean dependent var & 5224.783 \\
Adjusted R-squared & 0.855556 & S.D. dependent var & 4877.681 \\
S.E. of regression & 1853.801 & Akaike info criterion & 18.13817 \\
Sum squared resid & $1.51 \mathrm{E}+08$ & Schwarz criterion & 18.81282 \\
Log likelihood & -560.4215 & Hannan-Quinn criter. & 18.40395 \\
F-statistic & 20.63974 & Durbin-Watson stat & 1.188201 \\
Prob (F-statistic) & 0.000000 & & \\
\hline
\end{tabular}

Berdasarkan hasil output Eviews 6 pada tabel diatas, tampak bahwa nilai koefisien determinasi (R2) pada perusahaan-perusahaan LQ45 periode 2010-2013 sebesar 0,899. Hal ini menunjukkan bahwa variabel independen NPM, ROA, ROE, dan EPS mampu menjelaskan variasi variabel dependen Harga Saham sebesar $89,9 \%$ sedangkan sisanya $10,1 \%$ dijelaskan oleh variabel lain diluar variabel yang digunakan dalam penelitian.

\section{Pembahasan}

1. Analisis secara parsial

a. Berdasarkan hasil pengujian uji $t$ diatas maka didapat nilai Prob variabel NPM sebesar $0,0139<$ 0,05 sehingga dapat disimpulkan menerima Halyang berarti Net Profit Margin (NPM) berpengaruh signifikan terhadap harga saham. Semakin tinggi rasio NPM berarti laba yang dihasilkan oleh perusahaan juga semakin besar, maka akan menarik minat investor untuk melakukan transaksi dengan perusahaan yang bersangkutan. Karena secara teori jika kemampuan emiten dalam menghasilkan laba semakin besar, maka harga saham di pasar modal juga akan mengalami peningkatan, sehingga rasio ini mempunyai hubungan yang positif dengan harga saham.

b. Berdasarkan hasil pengujian uji $t$ diatas maka didapat nilai Prob variabel ROA sebesar 0,0031 < 0,05 sehingga dapat disimpulkan menerima Ha2yang berarti Return On Assets (ROA) berpengaruh signifikan terhadap harga saham. ROA digunakan untuk mengukur kemampuan manajemen dalam 
memperoleh keuntungan (laba) secara keseluruhan. Semakin besar ROA, semakin besar pula tingkat keuntungan yang dicapai oleh perusahaan tersebut dan semakin baik pula posisi perusahaan tersebut dari segi penggunaan asset, maka ROA memiliki hubungan yang positif dengan harga saham.

c. Berdasarkan hasil pengujian uji $t$ diatas maka didapat nilai Prob variabel ROE sebesar $0,0114<$ 0,05 sehingga dapat disimpulkan menerima Ha3yang berarti Return On Equity (ROE) berpengaruh signifikan terhadap harga saham. ROE digunakan untuk mengukur rate of return (tingkat imbalan hasil) ekuitas. Para analis sekuritas dan pemegang saham umumnya sangat memperhatikan rasio ini, semakin tinggi ROE yang dihasilkan perusahaan, akan semakin tinggi harga sahamnya.

d. Berdasarkan hasil pengujian uji $t$ diatas maka didapat nilai Prob variabel EPS sebesar 0,6398 > 0,05 sehingga dapat disimpulkan menolak Ha4 yang berarti Earning Per Share (EPS) tidak berpengaruh signifikan terhadap harga saham. EPS akan sangat membantu investor karena informasi EPS dapat menggambarkan prospek earning suatu perusahaan di masa yang akan datang, karena EPS menunjukkan laba bersih perusahaan yang siap dibagikan kepada semua pemegang saham perusahaan, maka semakin besar EPS akan menarik investor untuk melakukan investasi di perusahaan tersebut. Hal ini akan mengakibatkan permintaan akan saham meningkat dan harga saham akan meningkat. Disini terlihat bahwa EPS tidak berpengaruh signifikan terhadap harga saham disebabkan EPS bukanlah indikator utama yang pertama kali di lihat oleh investor dalam menanamkan modalnya pada suatu perusahan, masih ada indikator rasio lainnya yang perlu di perhatikan, lebih utamakan melihat Net Profit Margin (NPM), Return On Assets (ROA), Return On Equity (ROE), namun tidak menutup kemungkinan untuk mempertimbangkan rasio lain di luar rasio profitabilitas.

2. Analisis secara simultan

Berdasarkan hasil pengujian uji $\mathrm{F}$ diatas maka didapat nilai F-statistic sebesar 20,63974 dengan Probabilitas (F-statistic) sebesar 0,000000 < 0,05sehingga dapat disimpulkan menerima Ha5 yang berarti Net Profit Margin(NPM), Return On Assets (ROA), Return On Equity (ROE), dan Earning Per Share (EPS) secara simultan berpengaruh signifikan terhadap harga saham.

\section{KESIMPULAN DAN SARAN}

\section{Kesimpulan}

1. Hasil uji $\mathrm{t}$ pengujian hipotesis secara parsial diperoleh hasil bahwa tiga variabel independen yakni Net Profit Margin (NPM), Return On Assets (ROA), Return On Equity (ROE) mempunyai pengaruh yang signifikan terhadap Harga Saham. Sedangkan variabel independen Eearning Per Share (EPS) tidak berpengaruh signifikan terhadap Harga Saham.

2. Hasil uji $\mathrm{F}$ pengujian hipotesis secara simultan diperoleh hasil bahwa Net Profit Margin (NPM), Return On Assets (ROA), Return On Equity (ROE), dan Eearning Per Share (EPS) secara simultan berpengaruh signifikan terhadap Harga Saham.

3. Hasil pengujian koefisien determinasi (R2) diperoleh hasil $\mathrm{R}$ square sebesar 0,899. Hal ini menunjukan bahwa variabel independen Net Profit 
Margin (NPM), Return On Assets (ROA), Return On Equity (ROE), dan Eearning Per Share (EPS) mampu menjelaskan variasi variabel dependen Harga Saham sebesar 89,9\% sedangkan sisanya $10,1 \%$ dijelaskan oleh variabel lain diluar variabel yang digunakan dalam penelitian.

\section{Saran}

1. Untuk penelitian selanjutnya diharapkan untuk menambah beberapa sampel perusahaan yang lain yang telah update dalam LQ45 di periode berikutnya.

2. Variabel independen bisa ditambah dengan beberapa variabel lain yang merupakan rasio profitabilitas yang diperkirakan akan berpengaruh terhadap harga saham perusahaan.

3. Menambahkan periode tahun penelitian yang lebih update untuk lebih mengetahui tingkat konsistensi hasil penelitian.

\section{DAFTAR PUSTAKA}

Algifari. (2010. Statistika Deskriptif Plus: Untuk Ekonomi dan Bisnis. Edisi Pertama. Yogyakarta: Unit Penerbit dan Percetakan Sekolah Tinggi Ilmu Manajemen YKPN.

Asakdiyah, Salamatun. (2006). Manajemen Keuangan 1: Alat Analisis dan Aplikasi. Yogyakarta: Fakultas Ekonomi Universitas Ahmad Dahlan.

Darmadji, Tjiptono dan Hendy M. Fakhruddin. (2008). Pasar Modal di Indonesia: Pendekatan Tanya Jawab. Edisi Kedua. Jakarta: Salemba Empat.

Ghozali, Imam. (2009). Aplikasi Analisis Multivariate Dengan Program SPSS. Edisi Keempat. Semarang: Badan Penerbit Universitas Diponegoro.
Jogiyanto. (2010). Metodologi Penelitian Bisnis: Salah Kaprah dan Pengalaman Pengalaman. Edisi Pertama. Yogyakarta: BPFE Yogyakarta.

Kusuma, Desta. $\mathrm{R}$ dan Deny Ismanto. (2012). Modul Praktikum EViews. Yogyakarta: Jurusan Manajemen Fakultas Ekonomi Universitas Ahmad Dahlan.

Mardiyanto, Handoyo. (2009). Intisari Manajemen Keuangan. Jakarta: Grasindo.

Martono dan D. Agus Harjito. (2003). Manajemen Keuangan. Edisi Pertama. Yogyakarta: Ekonisia.

Mulyono, Sugeng. (2000). Pengaruh Earning Per Share (EPS) dan Tingkat Bunga terhadap Harga Saham. Jurnal Ekonomi dan Manajemen. Vol. 1 No. 2. Pascasarjana Universitas Gajayana, Malang.

Prastowo, Dwi. (2011). Analisis Laporan Keuangan: Konsep dan Aplikasi. Edisi Ketiga. Yogyakarta: Unit Penerbit dan Percetakan Sekolah Tinggi Ilmu Manajemen YKPN.

Sulistiyanto, Haris. (2013). Pengaruh Earning Per Share (EPS), Return on Assets(ROA), Return on Equity (ROE), Net Profit Margin (NPM), dan Price Earning Ratio (PER) terhadap Harga Saham (Studi pada Perusahaan Industri Farmasi di Bursa Efek Indonesia). Skripsi. Yogyakarta: Universitas Ahmad Dahlan.

Tandelilin, Eduardus. (2010). Portofolio dan Investasi: Teori dan Aplikasi. Edisi Pertama. Yogyakarta: Kanisius. 